\title{
VISSZATÉRÉS A PIACHOZ: FENNTARTHATÓ ÉLELMISZER-FOGYASZTÁS BUDAPESTEN
}

\author{
BACK TO THE MARKETPLACE: \\ SUSTAINABLE FOOD CONSUMPTION IN BUDAPEST
}

\author{
Kuslits Béla', Kocsis Tamás \\ 1PhD-hallgató, Budapesti Corvinus Egyetem Gazdaságföldrajz, Geoökonómia és Fenntartható Fejlódés Intézet \\ bela@kuslits.hu \\ egyetemi docens, Budapesti Corvinus Egyetem Gazdaságföldrajz, Geoökonómia és Fenntartható Fejlődés Intézet
}

\begin{abstract}
ÖSSZEFOGLALÁS
A fenntartható élelmiszer-termelés leggyakrabban két jellemző stratégia egyike mentén valósul meg: vagy egy külső szakértő fél minősíti az élelmiszert (címkézett termékek), vagy pedig az ellátási lánc rövidítésével (a piac lokalizálásával) a termelő és a fogyasztó közötti kommunikációt erősítik. Mindkét stratégia megtalálható Budapesten is. Kutatásunkban arra kerestük a választ, hogy milyen értékrendbeli különbségek figyelhetők meg a fenntartható és a konvencionális fogyasztási helyszínek vásárlói között, illetve hogy ezek a vásárlók hogyan ítélik meg a különböző élelmiszerek ár-érték arányát. Kérdőíves vizsgálatunk részletesen vizsgálta a fogyasztók attitűdjeit, amelyek meghatározzák, hogy hol és milyen termékeket vásárolnak. Eredményeink alapján a budapesti vásárlók öt jellemző csoportba sorolhatók, amelyek közül kettőt nevezhetünk kifejezetten a fenntartható élelmiszerek iránt elkötelezettnek. Ez az elköteleződés az esetek egy részében önérdekkövetésből ered, más esetekben a fogyasztók társadalmi vagy ökológiai felelősségvállalásból döntenek ezen termékek mellett. Annak ellenére, hogy vannak fogyasztók, akik elkötelezettek a fenntartható élelmiszerek mellett, az átlagos fogyasztó túl drágának ítéli ezeket a termékeket. Eredményeink lehetővé teszik olyan stratégiák kidolgozását, amelyek hatékonyan növelhetik a fenntartható élelmiszerek piaci részesedését.
\end{abstract}

\section{ABSTRACT}

Sustainable food production is often approached by one of two strategies: either an external party certifies the products (labelled food) or the supply chain is shortened (by localizing the market) in order to strengthen communication between consumer and producer. Both strategies can be observed in Budapest. In our research, we studied the consumer value differences among frequent buyers of sustainable and conventional food sources, and also the way they see the value of these products, compared to the prices. Our survey collected detailed information on consumer attitudes that determine where and what products they buy. Based on our results, consumers of food in Budapest can be sorted into five categories. Two of those groups are committed to sustainable food - one is more focused on individual benefits, the other is also 
taking responsibility for the social and environmental effects. Besides the existence of these two groups, average consumers find sustainable food products too expensive compared to their perceived value. Our results suggest possible strategies to increase the market share of sustainable food sources.

Kulcsszavak: rövid ellátási lánc, fenntartható élelmiszer-termelés, élelmiszer-minőség, fogyasztói értékrend

Keywords: short supply chain, sustainable food production, food quality, consumer values

\section{BEVEZETŐ}

Az élelmiszer a legfontosabb termékek egyike mind az egyes fogyasztók, mind a teljes társadalom szempontjából. Az, hogy mit eszik és hogyan étkezik valaki, nemcsak a személyes életét, de a tágabb környezetét is érinti: technológiák, munkahelyek, ökológiai hatások sokasága függ egyéni fogyasztói döntésektöl. Az azonban, hogy a fogyasztó végső soron mit és miért választ, nehezen megközelíthető kérdés, részben emiatt a komplexitás miatt: a vásárlói döntések akár másodpercek alatt megszületnek, az előzmények és a következmények mégis gyakran több kontinenst járnak be. A fogyasztók többnyire jó minőségü terméket keresnek. Az azonban, hogy mi a jó minőség, milyen szempontok szerint és milyen mértékü elvárásoknak kell megfelelnie egy terméknek ahhoz, hogy jó minőségűnek ítéljék, igen változatos. A termék tápláló és élvezeti értékén túl, sokak számára etikai szempontok is hozzátesznek ahhoz, hogy mit tartanak minőségnek.

Rosa Schleenbecker és Ulrich Hamm szerint a minőség fogalma a fogyasztók számára két részből tevődik össze: az alapvető érték, amely tartalmazza az egészségességet és a tápértéket, illetve a kiegészítő érték, amely az érzékszervi (gasztronómiai) és társadalmi szempontokat foglalja magába. Az azonban, hogy egy fogyasztó melyik tényezőt mennyire hangsúlyosan veszi figyelembe, változó. Kutatásukban, más munkákhoz hasonlóan, leírnak egy fogyasztói csoportot, akik jellemzően bioélelmiszert választanak, azonban többet várnak a hagyományos bio minősítésnél: az állatok életkörülményei és a termelés helye is fontos szempont számukra (Schleenbecker-Hamm, 2013). Klaus G. Grunert szerint fontos tudatosítani, hogy a minőséggel kapcsolatos fogyasztói igények, ezeknek az igényeknek a teljesülése a termelésben, valamint a fogyasztó erre vonatkozó percepciója három egymással csak mérsékelten összefüggő tényező. A termelők és fogyasztók közötti információs aszimmetria, tudás- és értékrendbeli különbség azt eredményezi a gyakorlatban, hogy a termékről kialakított kép könnyen lehet 
túlzottan pozitív vagy negatív is. A termékek etikai megítélése és piacképessége tehát összefügg, de a két tényező közötti kapcsolat bonyolult és ellentmondásos mind a konvencionális, mind az etikus termékek esetében (Grunert, 2005).

A jó minőség és társadalmi felelősségvállalás kulcsa lehet a termelés folyamatának átláthatósága, ami más módok mellett a termelés és értékesítés lokalizációjával segíthető elő. Damian C. Adams és Matthew J. Salois szerint a piacokon és az irodalomban egyaránt a „helyi” fokozatosan átveszi a „bio” szerepét. Ugyanazok a fogyasztók, akik a vegyszermentes mezőgazdaságban látták a számukra fontos értékek megvalósulását (legyen az egyéni egészség vagy fenntarthatóság), ma inkább a helyi kistermelők felé fordultak. Ennek a változásnak az oka a szerzők szerint az, hogy a nagyüzemi mezőgazdaság is egyre több bioterméket dob piacra, ezek azonban a fogyasztók egy csoportja számára a termelési lépték vagy más probléma miatt nem számítanak fenntarthatónak, még ha a vegyszermentességük nem is vitatott (Adams-Salois, 2010).

A vásárlók termékek környezeti és társadalmi hatásaihoz való viszonya általában véve ellentmondásokkal terhes, írja June Cotte és Remi Trudel. A legtöbb kutatás szerint a fogyasztók hajlandóak valamivel többet fizetni az etikusabb termékekért, mégis, ha az elvárt árat kérdezik tőlük, jellemzően ugyanazt az értéket adják az etikus és a konvencionális termékeknek. Az ellentmondásos átlag azonban rejt csoportokat, amelyek elkötelezettek az etikus fogyasztás mellett. Ezek a csoportok jellemzően kevésbé írhatók le demográfiai paraméterekkel, sokkal jellemzőbbek az értékrendükre utaló mutatók, például a politikai orientáció vagy a reklámok elutasításának mértéke (Cotte-Trudel, 2009).

Kutatásunkban a döntéseket befolyásoló számos tényező közül a fenntarthatóság szempontjából kiemelkedően fontos szempontokat vizsgáltuk a budapesti vásárlók körében. Eredményeink rámutatnak a hazai fenntarthatóélelmiszer-piac néhány olyan motívumára, amelyek utat mutathatnak a további fejlődéshez.

\section{A PIACTÉR: RÉGI MEGOLDÁS EGY MODERN PROBLÉMÁRA}

Thomas Princen szerint a gazdasági globalizáció mára kiteljesedő folyamata egyre több környezeti és társadalmi problémát kapcsol a termelési folyamatokhoz, ezek azonban jellemzően nem érzékelhetők a fogyasztók számára, mert a kulturális és térbeli távolság „elhomályositja és eltávolítja” a problémákat a fogyasztóktól. Egyik javasolt megoldása a klasszikus piac ideáljához való visszatérésben rejlik. A piactér egyfajta kollektív minőség-ellenörzési platformként is müködik, ahol sok termelő és sok vásárló találkozik, ahol könnyen össze lehet hasonlítani az árakat, sok esetben meg lehet kóstolni a termékeket, és a kis távolságok miatt elméletileg akár azt is megtehetik a vevők, hogy ellátogatnak a farmra, és megnézik, miként zajlik a termelés (Princen, 1997). 
Nézetünk szerint a fogyasztók többsége, még ha elméletileg nem is megalapozottan és részletekbe menően, de alapvetően tisztában van azzal, hogy gyakran káros környezeti hatások és társadalmi konfliktusok terhelik a termelést, és ez befolyásolja a termékek minőségét, valamint hogy az ár és a minőség között bizonyos mértékü összefüggés áll fenn. A termelők és a fogyasztók között információs aszimmetria figyelhető meg az élelemiszer termelési körülményeivel kapcsolatban.

Azoknak a fogyasztóknak, akik vásárlás előtt szeretnének behatóbban tájékozódni, két fő módja létezik az információs aszimmetria enyhítésének (Kuslits-Kocsis, 2018). Az egyik elérhető megoldás a címkézett, tanúsított termékek vásárlása (illetve a címkék tudatos figyelemmel kísérése, vizsgálata), a másik a helyi értékesítési formák előnyben részesítése, ahol a termelőnek személyesen lehet kérdéseket feltenni. Előbbi csoportba tartoznak a minősített biotermékek, a helyi védjegyes és fairtrade áruk, a különböző állatvédelmi minősítések, illetve a termékekhez kapcsolódó szén-dioxid-kibocsátást jelző címkék. Leggyakrabban a címkéket egy külső, harmadik szervezet ítéli oda az arra pályázó termelőknek bizonyos feltételek teljesülése esetén (Gallastegui, 2002). A címkék nemcsak a termelö és a fogyasztó közötti információs aszimmetria csökkentésére alkalmasak, hanem arra is, hogy a tudomány által feltárt releváns, de a felek által nem ismert összefüggéseket tömören és érthetően közvetítsék mindkét fél felé (Kocsis-Kuslits, 2019).

A magyarországi élelmiszerpiacon is megtalálhatók a védjegyek, illetve ezekkel párhuzamosan az utóbbi években egyre erősödik a kézmüves élelmiszerek és termelői piacok mozgalma (Benedek et al., 2014; Fertö et al., 2016). Az is megfigyelhetö, hogy a fogyasztók egy csoportja hajlandó magasabb árat fizetni egyegy termékért, ha azt valamilyen értékrend (egészség, fenntarthatóság, tradíció iránti vonzalom stb.) mentén átlag felettinek látja (Balogh et al., 2016; Szakály et al., 2017).

A hazai jogszabályok szerint a termelői piacokon kizárólag saját termékeiket értékesíthetik azok a kistermelők, akik az adott megyéből vagy a piac negyven kilométeres körzetéből jönnek (a területi korlátozás Budapesten nem érvényes). ${ }^{1}$ Ezek a szabályok elméletileg alkalmasak arra, hogy sok tekintetben kiküszöböljék azokat a Princen által is leírt jelenségeket, amelyek a környezeti és társadalmi problémákat láthatatlanná teszik. A szupermarketek kontinenseken átívelő beszállítói láncához képest valóban jelentős különbséget jelent az, hogy személyesen találkozhatunk a termelővel, visszajelezhetünk neki a korábban vásárolt termékről, és kérdéseket tehetünk fel a termelés folyamatáról. Azokat az értékesítési módokat, amelyek a termelö és fogyasztó közötti minél közvetlenebb kapcsolat megteremtésére törekednek, rövid ellátási láncoknak nevezzük. 
A termelői piac, illetve a termékek minősítése egy-egy intézményi keret, amelyben az élelmiszerpiaci környezetkárosítás (negatív externália) kiküszöbölése elvileg lehetséges lenne. A továbbiakban azt fogjuk bemutatni, hogy a fogyasztói attitüdök hogyan határozzák meg ennek az intézményi keretnek a müködőképességét, illetve megvizsgáljuk azokat az értékeket, amelyek szerepet játszanak a budapesti fogyasztók értékválasztásaiban.

\section{FENNTARTHATÓ ÉLELMISZER-FOGYASZTÁS BUDAPESTEN}

2017 májusában egy kérdőíves felmérést végeztünk budapesti piacokon és szupermarketekben. A kérdőív Anna Botonaki és munkatársai (2006) korábbi munkájára építve vásárlást befolyásoló értékekre kérdezett rá öt kategóriában: árérzékenység, egészségtudatosság, környezettudatosság, kényelem és felfedező attitűd. Ezek mellett demográfiai adatokat gyüjtöttünk, valamint arra kértük a válaszadókat, hogy becsüljék meg bizonyos termékek árát és ár-érték arányát a különböző értékesítési helyszíneken. A kutatási helyszínek között két szupermarket, két hagyományos piac, két termelői és két biopiac volt, mindegyik típusból egy Budán, egy Pesten.

A helyszínek kiválasztásánál arra törekedtünk, hogy az eredmények alapján az egyes vásárlási helyszíneken jellemző attitüdök legyenek összehasonlíthatók. A pesti és budai helyszínek közötti különbség elsősorban azért volt lényeges, mert így többféle szociológiai hátterü és anyagi helyzetü fogyasztónak is feltehettük a kérdéseinket, míg az egyes helyszíntípusok a beszállítói körükben különböznek leginkább. A szupermarketekre jellemző leginkább a globális beszállítói lánc. A hagyományos piacon nagyobb részt, de nem kizárólag, hazai élelmiszer kapható, ami nem minősített, jellemzően nagyüzemi származású. A biopiacon a származás helye nem, de a biominősítés jellemző, míg a termelöi piacon a termékek sokszor nem minősítettek, a származás helye és a termelő jellege a meghatározó.

Az egyik hipotézisünk az volt, hogy míg a piac és a szupermarket vásárlói összemosódnak és jellemzően elsődlegesen árérzékeny fogyasztókból állnak, a termelői piacon és a biopiacon a fenntarthatóság és egészségtudatosság mellett elkötelezett fogyasztók lesznek felülreprezentáltak. Arra számítottunk tehát, hogy a korábbiakban leírtaknak megfelelően, azok az értékesítési módok, amelyek az ellátási lánc nagyobb átláthatóságát teszik lehetővé, azokat a fogyasztókat vonzzák, akik számára az így hozzáférhető etikai szempontok fontosak akár annak árán is, hogy így magasabb áron jutnak a termékekhez. Az értékrend befolyásoló szerepe mellett a másik hipotézisünk az volt, hogy bár van valós árkülönbség a termelői és biotermékek, illetve a konvencionális megfelelőik között, a különbség mértékét a fogyasztók többsége felülbecsüli, és ezzel párhuzamosan túlzónak is tartja. 
A nyolc helyszínen felvett 156 kérdőívet az Agenda 2030 Humánökológia Kutatómủhely szemináriumán felkészített kérdezőbiztosok segítségével töltötték ki a válaszadók. A minta nem reprezentálja a magyar társadalmat, mivel minden piactípuson ugyanannyi válasz összegyüjtésére törekedtünk, függetlenül attól, hogy az összes fogyasztó hány százaléka látogatja az adott helyszínt. Ily módon vált lehetővé, hogy az arányaiban még alacsonynak mondható bio-, illetve termelöi piacon történő vásárlás körülményeit jobban feltárhassuk.

A vásárláshoz kapcsolódó attitüdjeik alapján a mintába került budapesti fogyasztók öt jól körülhatárolható csoportba sorolhatók (1. táblázat) klaszterelemzéssel (Ward method). Ez a csoportosítás segít megérteni, hogy milyen értékek és szociológiai adottságok határozzák meg az egyes fogyasztók döntéseit.

A válaszadók között a fenntartható élelmiszereket egyértelmúen preferálók két csoportba sorolhatók. Az első csoport [1] átlagosnak tekinti saját anyagi helyzetét, és fontos számára az élelmiszer egészségügyi hatása és termelési körülménye is. Ök tekinthetők leginkább olyannak, akik tudatos értékválasztás alapján döntenek a fenntartható élelmiszerforrások mellett - elsősorban biopiacon vásárolnak. Mellettük jellemző még a „tudatos jómódúak” [2] klasztere, akik 30-as, 40-es éveikben járnak, nem árérzékenyek, hagyományos üzletekben nem vásárolnak, de nem jellemző rájuk, hogy valamilyen érték hangsúlyos lenne a vásárlási döntéseikben. Az értékrendbeli elkötelezettséggel és az átlag feletti vásárlóerővel jellemezhetö fogyasztók mellett kirajzolódott egy olyan csoport is [3], amely az adatok alapján szociológiailag kevésbé megragadható, mégis jelentős hányadát adta a válaszadóknak. Ök jellemzően termelői piacra járnak, de a kérdőív alapján nem látható a motivációjuk. Elképzelhető, hogy valamilyen olyan szempont alapján döntenek, amely a környezeti és társadalmi hatások szempontjából kevésbé releváns, például gasztronómiai preferenciák - jelenlétük azonban nagyon fontos jelzője annak, hogy további kutatásokra is szükség van, ha a fogyasztói attitüdöket meg akarjuk érteni. Két olyan csoport azonosítható a válaszadóink között, akikre nem jellemző a tudatosan fenntartható fogyasztás. Egyik ilyen a ,hagyományos háziasszonyok" [4] csoportja, akik jellemzően piacon vásárolnak, rendkívül árérzékenyek, és valószínúleg ezért nem járnak termelői és biopiacra sem, jellemzően elégedetlenek az anyagi helyzetükkel. A csoport többsége 45 év fölötti nő. Szintén látványosan kirajzolódik az ,egyetemista korú fiatalok” [5] csoportja, akik az áron kívül nem sok szempontot tartanak fontosnak az élelmiszerek kiválasztásában, és az esetek döntő többségében szupermarketekben vásárolnak.

A fenntartható termékek fogyasztói amellett, hogy hajlandóak (és képesek) magasabb árat fizetni az élelmiszerért, mint a hagyományos helyszínek látogatói, számos szempontból jelentősen különböznek egymástól is. Fontos különbség például, hogy míg egyesek számára elsősorban azok a szempontok fontosak, amelyek saját életük szempontjából relevánsak, mások olyan tényezőket is figyelembe vesznek, amelyeknek tőlük távolabb van csak jelentősége. Másként fogalmazva, 
míg a fogyasztók egyik csoportjának az egészséges, illetve gasztronómiai szempontból kiemelkedő termékek érnek többet, mások számára a fenntarthatóság, a vidékfejlesztés és más, elvontabb szempontok is hangsúlyosak a drágább termék kiválasztásakor. Megerősítést nyert tehát az első hipotézisünk, mely szerint a konvencionális piacon a fogyasztók elsősorban az olcsó termékeket keresik, míg a fenntarthatóbb piacokon - nagyobb árrugalmasság mellett - az élelmiszer-termeléshez köthetö társadalmi értékek is fontos szerepet játszanak. Mindezek mellett a termelői piacok vásárlói motivációinak mélyebb megértéséhez további kutatások szükségesek.

1. táblázat. A budapesti élelmiszerpiacokon azonosított fogyasztói csoportok és attitűdjeik

\begin{tabular}{|c|c|c|c|c|}
\hline Csoport & $\begin{array}{l}\text { Társadalmi } \\
\text { jellemzők }\end{array}$ & Attitüd & $\begin{array}{c}\text { Jellemző } \\
\text { vásárlási hely }\end{array}$ & Arány \\
\hline $\begin{array}{l}\text { [1] zöld } \\
\text { középosztály }\end{array}$ & $\begin{array}{l}\text { sokféle életkor, } \\
\text { jellemzően nő, } \\
\text { lakhelye közelében } \\
\text { vásárol, keresetével } \\
\text { elégedett }\end{array}$ & $\begin{array}{l}\text { vitaminok és } \\
\text { környezetbarát } \\
\text { származás meghatározó, } \\
\text { elolvassa a címkéket, } \\
\text { kerüli az adalékokat, } \\
\text { nem árérzékeny }\end{array}$ & $\begin{array}{l}\text { biopiac és } \\
\text { szupermarket }\end{array}$ & $29 \%$ \\
\hline $\begin{array}{l}\text { [2] tudatos } \\
\text { jómódú }\end{array}$ & $\begin{array}{l}\text { 32-46 éves, magas } \\
\text { kereset, ezzel } \\
\text { elégedett, autóval } \\
\text { jár }\end{array}$ & $\begin{array}{l}\text { nem árérzékeny, a } \\
\text { környezetbarát forrás és } \\
\text { a termelési körülmények } \\
\text { meghatározóak, az } \\
\text { egészséges táplálkozás } \\
\text { kevésbé }\end{array}$ & $\begin{array}{l}\text { biopiac, ritkán } \\
\text { termelői }\end{array}$ & $21 \%$ \\
\hline $\begin{array}{l}{[3] \text { termelöit }} \\
\text { kedvelő }\end{array}$ & $\begin{array}{l}\text { 15-32 éves, } \\
\text { alacsony keresetü, } \\
\text { ezzel elégedetlen }\end{array}$ & adalékanyagokat kerüli & $\begin{array}{l}\text { főként termelői, } \\
\text { hagyományos } \\
\text { piac, } \\
\text { szupermarket } \\
\text { soha }\end{array}$ & $18 \%$ \\
\hline $\begin{array}{l}{[4]} \\
\text { hagyományos } \\
\text { háziasszony }\end{array}$ & $\begin{array}{l}47-63 \text { éves, } \\
\text { jellemzően nő, } \\
\text { keresetével } \\
\text { elégedetlen, } \\
\text { tömegközlekedéssel } \\
\text { jár, lakhelye } \\
\text { közelében vásárol }\end{array}$ & $\begin{array}{l}\text { zöld csomagolás } \\
\text { meghatározó, } \\
\text { árérzékeny, egyszerüen } \\
\text { elkészíthető ételeket } \\
\text { keres }\end{array}$ & $\begin{array}{l}\text { piac, termelői } \\
\text { piac ritkán }\end{array}$ & $14 \%$ \\
\hline $\begin{array}{l}{[5]} \\
\text { egyetemista } \\
\text { korú fiatalok }\end{array}$ & $\begin{array}{l}\text { 15-32 éves, férfi, } \\
\text { jó anyagi helyzetü, } \\
\text { elégedett }\end{array}$ & $\begin{array}{l}\text { nincsenek határozott } \\
\text { minőségi elvárásai }\end{array}$ & $\begin{array}{l}\text { kizárólag } \\
\text { szupermarket }\end{array}$ & $18 \%$ \\
\hline
\end{tabular}


Az árakra és ár-érték arányra vonatkozó kérdésekből azt a következtetést vontuk le, hogy bár a fogyasztók számottevő része tisztában van azzal, hogy a fenntarthatóbb vagy egészségesebb élelmiszer-termelési módok egyben drágábbak is, a magasabb árakat a teljes minta átlagában mégis túlzottnak tekintik (elsősorban a biotermékeknél, kisebb mértékben a helyi termelők esetében), azaz nem egyértelmü számukra, hogy a többletérték annyival magasabb termelési költséget is jelent, amekkora a látható árkülönbség. Ez az eredmény megerősítette a második hipotézisünket. Az azonosított csoportok értékrendje és vásárlóereje alapján mégis van helyük ezeknek a drágább termékeknek a magyar élelmiszerpiacon, hiszen a piac egy számottevő része kifejezetten tudatosan áll a termékek eredetéhez, egészségi és társadalmi hatásához. A fenntartható élelmiszerek termelése és fogyasztása jelenleg jóval kisebb piac, mint a teljes magyar élelmiszerpiac, a tudatos vásárlói csoportok azonban jó kiindulópontot adhatnak egy fokozatos növekedéshez. A két fő eredményünk egymáshoz való viszonya külön figyelmet érdemel. Míg egyértelmü, hogy a fogyasztók egy része értékként tekint a fenntarthatóbb élelmiszerre, és hajlandó is többletköltséget vállalni érte, az átlagos válaszadó számára ezek a termékek túlárazottnak látszanak. Ez jól szemlélteti, hogy az információs aszimmetria csökkentésére lenne szükség a fenntartható élelmiszerpiac nagyobb térnyeréséhez.

A fenntarthatóbb élelmiszerpiac felé való elmozdulásban olyan intézkedések látszanak a leginkább hasznosnak, amelyek a valós élelmiszerpiacot a piac elméleti modelljéhez viszik közelebb: javítják a fogyasztók információhoz való hozzáférését, és segítik annak értelmezését (azaz csökkentik az információs aszimmetriát). A konvencionális élelmiszerek fajlagosan ugyan valóban olcsóbbak, mint a fenntarthatóbb versenytársaik, a különbség azonban kisebb, mint amit a fogyasztók átlagosan feltételeznek. A válaszadók tehát vagy a társadalmi értékek árba való beépítését tartják túlzónak, vagy csak téves információkból vonják le a következtetéseiket. Valószínü, hogy mindkét lehetőség szerepet játszik, a kettő viszonyát azonban csak további kutatással lehetne tisztázni. Kihívást jelent ennek a kérdésnek a megválaszolásában, hogy az objektív információs aszimmetria mellett az információforrások hitelessége és a különböző szempontok összevetése is nehezíti a fenntarthatóság elveinek egyértelmü kommunikációját.

A piac klasszikus modellje tehát az eredményeink alapján kedvező környezete lenne a fenntartható élelmiszerek terjedésének, olyan szabályozásra van tehát szükség, amely ezt minél hatékonyabban segíti megvalósulni a gyakorlatban is. Ez a támogatás - hatékonyan - alapvetően két formában valósulhat meg. Az első azoknak az intézményi kereteknek (helyi piacok és hasonló, rövid ellátási láncú kezdeményezések) az erősítése, amelyek az információk ,elhomályosítását” nem teszik lehetővé, a második az olyan kommunikációs csatornák kidolgozása (címkék), amelyek egy-egy termékröl nyújtanak többletinformációt a fogyasztóknak. Néhány termék esetében (például tojás) ezek a címkék már elterjedtek, kérdéses 
azonban, hogy a fogyasztók mennyire vannak tisztában a jelölések értelmével. Összefoglalóan tehát elmondhatjuk, hogy a termelési és értékelési folyamatba közvetlenül be nem avatkozva, de a fogyasztóknak különböző módokon többletinformációt nyújtva, közelebb léphetünk a fenntartható élelmiszer-termeléshez. Ezek a stratégiák - kisebb különbségekkel - mind piaci, mind kormányzati szereplők számára elérhetők.

Köszönetet mondunk azoknak a hallgatóknak, akik 2017 tavaszán részt vettek az Agenda 2030 Humánökológia Kutatómühely szemináriumán, és kérdezőbiztosként hozzájárultak ennek a kutatásnak a megvalósulásához: Fóris Edina, Horváth Nóra, Horváth Richárd, Kovács Ágnes, Sipos Flóra, Szánthó Flóra, Varga Attila. A kutatás a „Szándékos költségáthárítás a döntéshozatalban” címü OTKA (\#120183) pályázat keretében készült.

\section{IRODALOM}

Adams, D. C. - Salois, M. J. (2010): Local versus Organic: A Turn in Consumer Preferences and Willingness-to-Pay. Renewable Agriculture and Food Systems, 25, 4, 331-341. DOI: 10.1017/ S1742170510000219, http://centaur.reading.ac.uk/17963/1/RAFS_online_version.pdf

Balogh P. - Békési D. - Gorton, M. et al. (2016): Consumer Willingness to Pay for Traditional Food Products. Food Policy, 61, 176-84. DOI: 10.1016/j.foodpol.2016.03.005, https://www.sciencedirect.com/science/article/pii/S0306919216300161

Benedek Zs. - Fertő I. - Baráth L. et al. (2014): Termelői heterogenitás a rövid ellátási láncokban: a piacokon értékesítő gazdák jellemző különbségei. Gazdálkodás, 4, 307-319. http:// real.mtak.hu/16488/1/Benedek-Fert\%C5\%91-Bar\%C3\%A1th-T\%C3\%B3th_Gazd\%C3\%A11kod\%C3\%A1s\%202014.4.pdf

Botonaki, A. - Polymeros, K. - Tsakiridou, E. et al. (2006): The Role of Food Quality Certification on Consumers Food Choices. British Food Journal, 108, 2, 77-90. DOI: 10.1108/00070700610644906, https://www.researchgate.net/publication/240601668_The role_of_food_quality_certification_on_consumers'_food_choices

Cotte, J. - Trudel, J. (2009): Socially Conscious Consumerism. Network for Business Sustainability, https://nbs.net/p/systematic-review-socially-conscious-consumerism-e201164a-9ce8-484f-90a2-d99e5dbf3e84

Fertő I. - Major, A. - Podruzsik, Sz. (2016): Be- és kilépés egy érett iparágban: a magyar kisüzemi sörfözdék esete. Élelmiszer, táplálkozás és marketing, 12, 1, 39-46. http://journal.ke.hu/index. $\mathrm{php/etm/article/view/183/670}$

Gallastegui, G. I. (2002): The Use of Eco-Labels: A Review of the Literature. European Environment, 12, 6, 316-31. DOI: 10.1002/eet.304, https://onlinelibrary.wiley.com/doi/pdf/10.1002/ eet. 304

Grunert, K. G. (2005): Food Quality and Safety: Consumer Perception and Demand. European Review of Agricultural Economics, 32, 3, 369-91. DOI: 10.1093/eurrag/jbi011, https://pdfs.semanticscholar.org/ffca/1b35aa58e0b245e54cf30cc3351a02c4e3a7.pdf

Kocsis T. - Kuslits B. (2019): Multidimensional Labelling: Closing the Sustainability Information Gap between Producers, Consumers and Sustainability Science in the Food Sector. Periodica 
Polytechnica Social and Management Sciences, 27, 1, 9-16. DOI: 10.3311/PPso.12594, https:// pp.bme.hu/so/article/view/12594/8239

Kuslits B. - Kocsis T. (2018): Körforgás, visszacsatolás a fenntartható élelmiszerpiacon. Lépések, 23, 2, 6-7. http://kovet.hu/wp-content/uploads/2018/09/lepesek_72.pdf

Princen, T. (1997): The Shading and Distancing of Commerce: When Internalization Is Not Enough. Ecological Economics, 20, 3, 235-53. DOI: 10.1016/S0921-8009(96)00085-7, https:// www.researchgate.net/publication/222303488_The_Shading_and_Distancing_of_Commerce_When_Internalization_Is_Not_Enough

Schleenbecker, R. - Hamm, U. (2013): Consumers Perception of Organic Product Characteristics. A Review. Appetite, 71, 420-29. DOI: 10.1016/j.appet.2013.08.020

Szakály Z. - Popp J. - Kontor E. et al. (2017): Attitudes of the Lifestyle of Health and Sustainability Segment in Hungary. Sustainability, 9, 10, 1763. DOI: 10.3390/su9101763, https://www. mdpi.com/2071-1050/9/10/1763/htm 